\title{
Providence and Publicity in Waiting for a Creationist Theme Park
}

\author{
James S. Bielo
}

June 2012. It is a few minutes after 9am, and I am sitting in the boardroom of a Kentucky design studio, the headquarters for a creationist theme park in the making. Ark Encounter - with a literalist replication of Noah's ark depicted in the Book of Genesis as its centrepiece - was a park with an uncertain future at the time. The morning staff meeting had just ended; I lingered afterward with the design team leader, Patrick, and an administrative assistant for the Answers in Genesis ministry, Sandy. They continued discussing the meeting's closing topic, details for a fundraising event to be held later in the month. As the conversation ended, Sandy stood looking at a piece of concept art for the park.

'It's so beautiful', she said earnestly to no one in particular. 'It is,' Patrick responded flatly, 'maybe it'll happen, maybe it won't.' After eight months of fieldwork at the studio, this was the first time I had heard doubt voiced publicly about if, not when, the project would materialize. The force of the doubt was amplified by Patrick's leadership status as Ark Encounter's creative director. Everyone dispersed to their offices and cubicles as usual, but his words hung in the air, unresolved.

Ark Encounter did not stay unresolved. The project opened to the public in July 2016, more than two years after its initially scheduled opening. Across twenty or so uncertain months of waiting, from spring 2012 through early 2014, media reports focused on the project's fundraising troubles. News story after news story questioned whether legal challenges regarding the park's application for enrolment in a state tax reimbursement programme had injected investors with 
anxious caution. Behind the scenes, among the cubicle desks of Patrick and his team, a different story unfolded. This chapter explores the team's experience of the uncertain months and develops two analyses: the forms of creative labour and theological commitment that filled the team's waiting. Interspersed with these analyses, I reflect on my fieldwork experience with the team and ask how different forms of waiting shaped this particular ethnographic encounter.

How might the team's experience inform a comparative anthropology of waiting as a process? Ghassan Hage (2009) argues that waiting is a lively opportunity to pose questions about agency. Is waiting active or inactive, a form of action or the deferment of action? Brun (2015) argues that the 'protracted uncertainty' experienced by Georgian refugees is realized as 'agency-in-waiting', producing both frustrated boredom and a future-oriented hope. Similarly, Kwon's (2015) work with married Chinese couples waiting to be reunited after transnational migration to Korea finds waiting to be 'an active attempt to realize a collectively imagined future' (479). While the Ark team's creative process was at the mercy of broader institutional efforts to raise money, and by extension broader political-economic conditions that frustrated fundraising, their waiting was anything but passive. Through creative labour, they played a pivotal role in advancing the ministry's fundraising agenda.

The Ark team also illuminates how waiting is a phenomenologically rich and revealing process, reflecting cultivated dispositions and the structural conditions that produce forms of waiting (Hage 2009). Comparative ethnography has explored this in diverse settings, from displaced refugees (Brun 2015) to urban welfare offices (Auyero 2011). Experiences of waiting range qualitatively from hope to boredom, uncertainty, anxiety, vulnerability and impatience. As the Ark team's waiting shifted into its own form of protracted uncertainty, the team negotiated doubt. They never doubted the purpose or worthiness of their mission, but as Patrick's unease in the opening vignette suggests, uncertainty crept in about if, when and how their project to deliver a creationist theme park to the public would materialize. Pelkmans (2013) argues that commitment and doubt are mutually 'implicated' (4), which was certainly true for the team. Doubts about whether or not Ark Encounter would materialize engaged Christian dispositions about what it means to be faithful and trust God. As I illustrate below, the interplay of doubt, hope, commitment and creative labour characterized the team's experience of waiting. 


\section{Public ambitions}

Ark Encounter is a project of Answers in Genesis (AiG), a creationist ministry based in northern Kentucky, just across the Ohio River from Cincinnati. The ministry was founded in 1994 by three former employees of the Institute for Creation Research (ICR). Founded in San Diego in 1972, ICR was one of the first organizations dedicated to promoting 'creation science' and continues today, although relocated to Dallas. Its late founder, Henry Morris, helped launch the modern creationist movement with his 1961 co-authored book The Genesis Flood. Since its founding, AiG has fashioned itself as a 'popular' complement to ICR, advancing the same mission of teaching creationism grounded in biblical literalism but aiming to reach a much broader audience (Numbers 1992).

The populist strivings of AiG garnered national attention in 2007 when it opened the Creation Museum in northern Kentucky. The 75,000 square foot facility was a $\$ 30$ million project, materializing the creationist worldview through interactive exhibits, multi-media shows, gardens, and a petting zoo (see Figure 5.1).

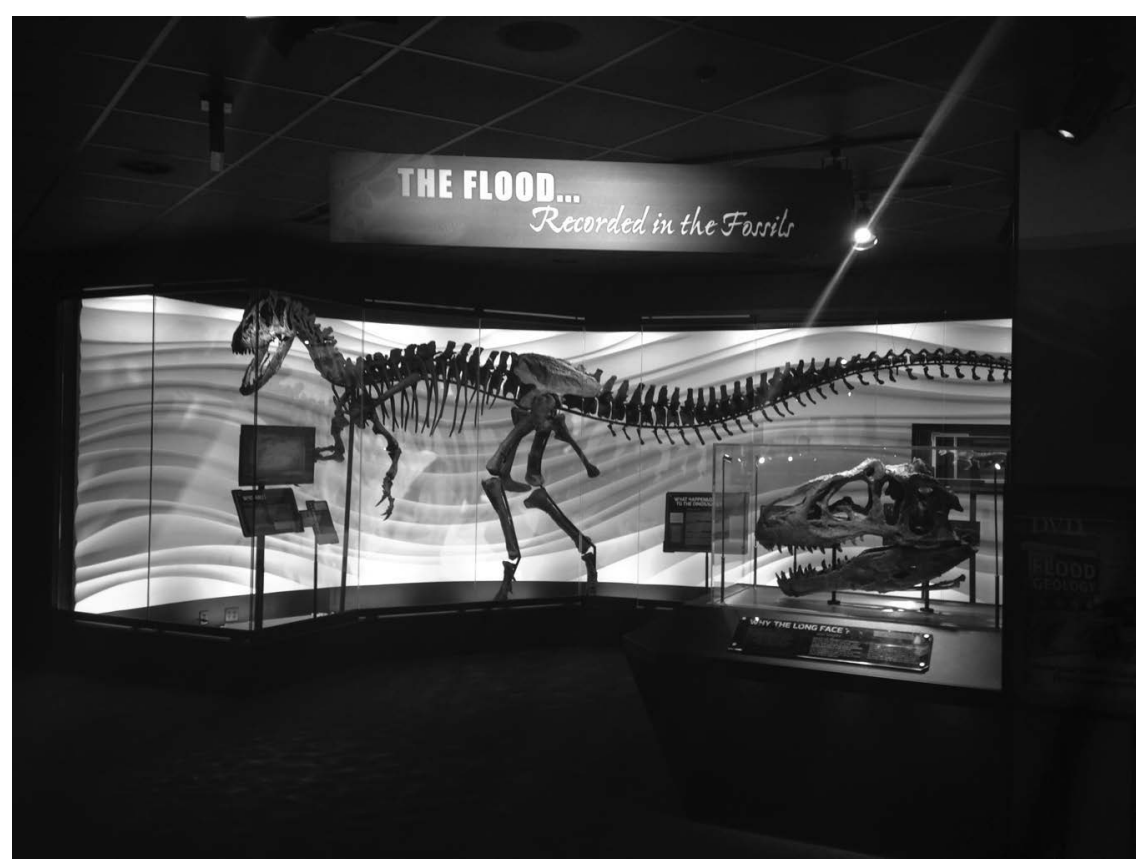

Figure 5.1 Exhibit display at The Creation Museum in Petersburg, Kentucky. Photo by author 
While dozens of creation museums exist on the American landscape, AiG's museum is the largest and most technologically sophisticated. By mid-2015 the museum had welcomed over two million visitors, and has emerged as the primary public face of modern creationism in the United States (Trollinger and Trollinger 2016; cf. Bielo 2016a).

With the museum as its epicentre, $\mathrm{AiG}$ functions like other influential fundamentalist organizations - as an empire of cultural production (Harding 2000). They publish books and periodicals, coordinate a research journal, produce films and radio programmes, curate an extensive online library of resources, design Christian home-schooling curricula, host summer Bible camp retreats for kids, and organize creation science teaching tours on Alaskan cruises and Grand Canyon hiking/rafting expeditions. The ministry's most recognizable face, Ken Ham, travels extensively to speak at churches and conferences, maintains an active weblog, hosts a daily online radio programme, and is often asked to speak as a representative voice of Christian conservatism on CNN and other major media outlets. The museum, Ham and all of AiG's materials are anchored by two pillars: a fundamentalist reading of scripture and a vehement critique of evolutionary science as a moral danger to the world (Butler 2010).

Every day, Answers in Genesis performs the work of religious publicity. I adopt this term from Matthew Engelke (2013), who presents it as a critical reassessment of how to study the presence of religion in public life. 'When we talk about "public religion" today we are often actually talking about "religious publicity" (xv). By this he means that the status of religion being public should not be taken for granted. Instead, 'public' should be understood as a status that is actively pursued, achieved, promoted and managed by socially positioned religious actors who are possessed by particular strategic aims. This reassessment emerges from Engelke's ethnographic work with the British Bible Society. Through campaigns in multiple English cities, from holiday displays to billboards, the Bible Advocacy team sought to 'counteract the idea that religion ought to be, or even must be, a private affair' by 'trying to promote and in many cases improve the image, relevance, and uptake of the Bible' (xiv).

The religious publicity of Answers in Genesis is defined by several interlaced ambitions. First, they seek to educate the public about creationism. This is essentially about circulating distinctive creationist claims grounded in a strict fundamentalist literalism, such as a 6,000-year-old earth, the reality of a global flood that killed all humans except Noah and his family, and the historical coexistence of humans and dinosaurs. This basic ambition props up two further aims: to generate and foster doubt about the authority of evolutionary science, 
and to simultaneously bolster the legitimacy of creationism. This double-edged strategy of detracting and producing authority supports other creationist efforts, such as manoeuvring to influence public school science curricula. AiG also hopes to create alternative digital and brick-and-mortar spaces of pedagogy, devotion and religious entertainment. The Creation Museum is a safe haven for committed creationists who are wary and suspicious of evolutionary-infused science and natural history museums. Finally, the religious publicity of the ministry is evangelistic. They seek to proclaim a fundamentalist Protestant theology, hoping that non-fundamentalists will, immediately or eventually, experience spiritual conviction and a born-again conversion or rededication.

When Ark Encounter opened in July 2016, it became the largest, most expensive expression of these ambitions. It capitalized on the ministry's work and success since 1994, which emerged from ICR and other institutions that comprised the early infrastructure of the modern creationist movement.

\section{Ark Encounter}

Set on 800 acres ( 324 hectares) of Kentucky rolling hills - 40 miles (64 kilometres) south of Cincinnati - the park's centrepiece is an all-wooden re-creation of Noah's ark, built to creationist specification from the text of Genesis 6-9. If the park is profitable, subsequent stages will be added to feature other materialized biblical replicas, such as the Tower of Babel. All tolled, the park is projected to cost more than $\$ 170$ million. The completed ark required nearly four million board feet (nearly 9,000 cubic metres) of timber, stands 51 feet (15 metres) tall, 85 feet (26 metres) wide, 510 feet (155 metres) long, and contains more than 1,00,000 square feet (9,290 square metres) of themed exhibit space (see Figure 5.2).

Visitors to the park progress through three decks on the ark filled with a mix of sculpted animals, animatronic figures, interactive displays, multimedia exhibits, food vendors and children's play areas. Each deck is organized by a particular affective experience.

Deck One centres on the drama of Noah and his family following the closing of the ark door. They are relieved to have escaped a terrifying storm, they have just witnessed mass death and they are anxious about the weeks ahead. The creative team always talked about Deck One as the 'darkest' of the decks, indexed sensually by low levels of lighting. The storm will be audible; visitors hear sounds of wind, rain, thunder and debris banging against the ark's sides. Noah and his family comfort the confused and disturbed animals and each other amid the difficult conditions. 


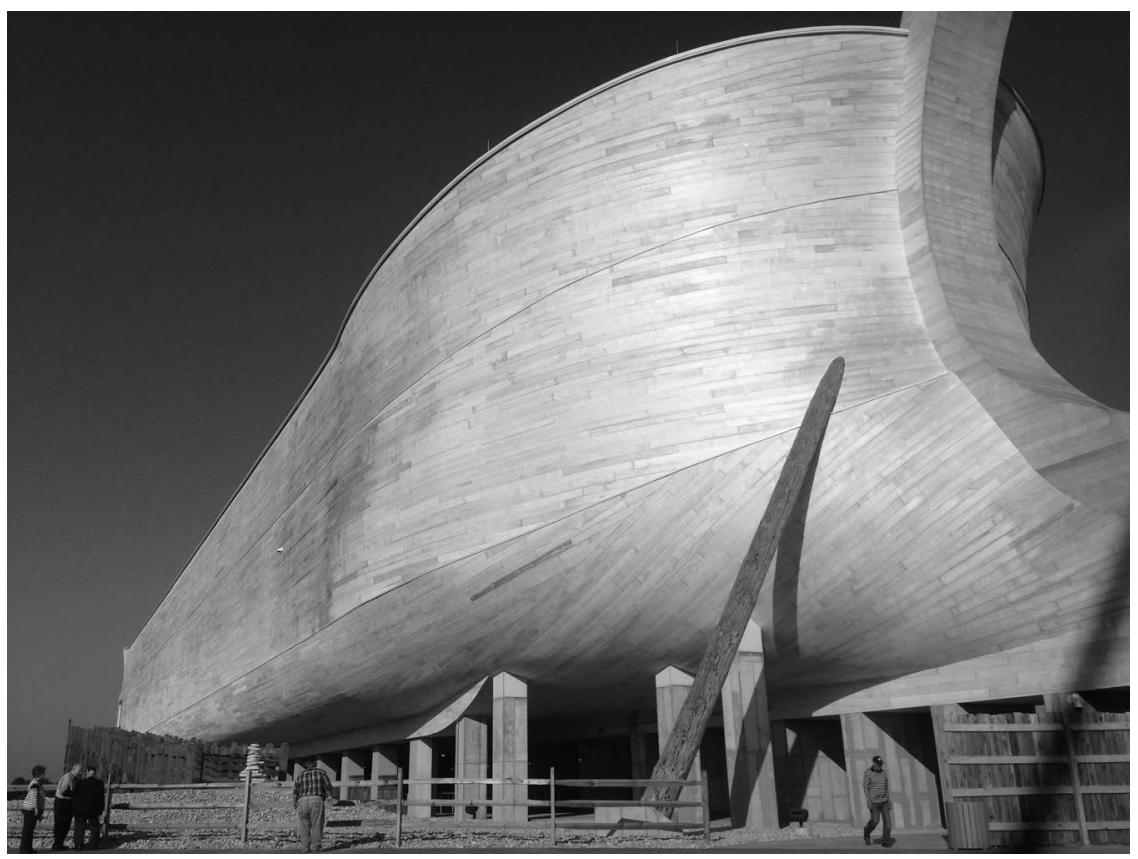

Figure 5.2 Ark Encounter in Williamstown, Kentucky. Photo by author

Deck Two focuses on the tasks and challenges of living on the ark. Noah and his family are settled, going about their liminal living: the daily grind of tending the onboard garden, caring for the animals and managing daily routines. This is designed as the primary 'how-to' deck, addressing numerous 'practical' issues about this biblical story. How did Noah and his family feed all the animals? What did they do with all the animal waste? How were air, water and sunlight distributed? What did Noah's workshop and library look like? By addressing these questions, Deck Two emphasizes the creationist claim that pre-flood people were capable of incredibly sophisticated technology because of their long lifespans (in their literalist reading, Noah lived to be 950 years old).

Deck Three continues themes from the first two decks and introduces several new experiences. More exhibits teach about animal kinds. More exhibits address how-to matters, such as what the passengers' living quarters were like and what technology Noah used to build the ark. Deck Three also captures the salvific realization that God's wrath has been expended, the storm is over, the waters receded, the eight passengers spared and the whole world is now theirs. This experience of awe transitions into creationist teaching points about post-flood life, such as the Tower of Babel dispersal of languages and people groups. Deck 
Three most intentionally teaches creationist typological hermeneutics, which interprets the Noah story as a type of salvation foreshadowing Jesus.

As visitors move through these three decks, 132 exhibit bays (44 per deck) combine to present a creationist narrative about the steadfast faithfulness of Noah and his family, their salvation, and, ultimately, the fundamentalist Gospel. The iconicity of moving from darkness to light, from judgement to salvation, was a very self-conscious decision by the creative team. They want visitors to experience this narrative progression as they walk, physically impacted by the affective force of sensory and material immersion.

Ark Encounter is a $\$ 170$ million testimony. It is missionization, massively materialized, performed in the key of biblical literalism, and organized by a strategic model of religious conversion: plausibility-immersion. First, the team sought to demonstrate the historical plausibility of the Noah story. They begin with the premise that it was physically and technologically possible for Noah to have built the ark described in Genesis 6. The project claims to use the exact dimensions detailed in scripture and only building materials that would have been available to Noah, namely timber and iron. Through different exhibits, the team portrays tools and techniques Noah might have used, although the project's publicity materials repeatedly explain that modern construction technology (e.g. cranes) was necessary, for instance, to complete construction within the timeframe required by building permits.

However, plausibility alone is not enough. Noah's story cannot merely be told; it must be felt. Affective response plays a vital role in this model of conversion. For them, success is not simply figured as effectively articulating the details of creationist doctrine; it is about effectively engineering an experience that compels non-creationist visitors towards conversion. What was the pre-flood world like, the one so wicked that God decided death was the only adequate judgement? What was it like to be surrounded by mass extinction? What was Noah's experience in building the ark, and preparing for the weeks on board? How did it feel to be inside the ark when the door closed; to hear the fierce storm outside and the cacophony of animals? What was the experience of living on the ark day after day? And, what was it like when the dove did not return, to see the rainbow and be the centre of God's saving grace?

An immersive experience promises to bridge the gap between plausibility and believability, and the logic of immersive entertainment is the engine that propels the team's creative labour (Stromberg 2009). To be immersed in the creationist past is to be immersed in a past where a universal flood killed everyone on earth except eight people. Six of these eight people, Noah's three sons and their wives, 
are the genetic ancestors for all modern humans. All the world's animals are the result of microevolution from the limited number of animal kinds brought onboard the ark. In this past, the earth is roughly 6,000 years old, not roughly 4.5 billion years. Human beings are a special creation of God, not the result of evolutionary processes. All animal kinds, including dinosaurs, coexisted with humans. Pre-flood human lifespans were dramatically longer, Noah building the ark when he was 600 years old and living to 950 . The play of this experience is about being immersed in a history, biology and anthropology that works in contrast to that of modern science. At its core, this immersive play is dialogic and ideological, presented as a direct alternative to the scientific past of evolution.

The creative team banks on park visitors becoming caught up in this creationist past. They want to spark our as-if imagination, igniting our capacity as homo ludens to engage in playful reverence for biblical miracle, creationist history and fundamentalist truth. They understand themselves as creators of the conditions for conversion, but take no responsibility for immediate or eventual spiritual changes. Patrick explained to me during an interview that the team's job is to provoke visitors to say, "Wow! Maybe that was possible. Maybe that did happen." That's all we can do. The rest is up to the Holy Spirit. Call people to the Church. All we can do is open the door and give them something to think about, and then the rest is up to God to save them.' The team never wavered in their commitment to this human-divine collaboration throughout the process of waiting, but they did question when God would allow the project to continue and why it stalled. Their waiting did not linger on gaining clear answers to these questions; they simply endured them, worked in the meantime, and hoped that God would deliver the necessary funds.

\section{Waiting timelines}

Ark Encounter was first announced on 1 December 2010. The Governor of Kentucky - joined by local politicians, Ark representatives and a room full of media personnel - held a public press conference to announce the project as the newest addition to the state's tourism industry. The event intended to clarify why a faith-based project was applying for a sales tax reimbursement programme under the Kentucky Tourism Development Act. The brief question-answer session operated primarily in a legal register, posing and fielding inquiries about Ark Encounter's constitutional legitimacy. Was it a violation of the prohibition against state establishment of religion for a faith-based project to receive a taxpayer-funded economic incentive? 
I learned misway through fieldwork that this press conference was premature for AiG. They were not ready to release project details, but their application for the tax reimbursement programme would be filed as a public record and word was bound to spread quickly. For the ministry, it was a choice of managing religious publicity: announce on their terms or be framed by the 'secular' media. At the time, Ark Encounter was not to be opened in phases, but as a complete attraction. The recreated ark was always the centrepiece, but the initial plan also included the Babel replica; a 'journey through Biblical history'; an SFX park ride narrating biblical events connecting Abraham and Moses; a 'Walled City'; an immersive area depicting 'pre-Flood society'; and a 'First-Century village', depicting everyday life in the Holy Land at the time of Jesus. All of the early concept art for the project showed this whole-park vision. When the press conference was held in December 2010, AiG had secured the 800-acre parcel of land, hired the architectural and engineering firm, and initiated the process of securing all of the necessary building permits. While unable to pinpoint an exact date, they declared with no qualifications that Ark Encounter would open during spring 2014.

By November 2011, the ministry had decided to change to a phasedconstruction plan. Phase One, still linked to the spring 2014 opening date, would include only the ark and a petting zoo. By spring 2012, the ministry had stopped saying 'spring 2014' on anything physical or digital. As the team entered this period of protracted uncertainty, a distinct shift in their horizon of expectations set in (Jansen 2014). Their creative labour shifted from the future park to present-time marketing and publicity. Reading back through my field notes, this shift is clearly marked. In early February 2012, my day at the studio was flush with activity; a six-hour, nearly non-stop meeting that discussed details ranging widely from the immersive aspects of exhibits to where the restrooms were to be located. For my return a few weeks later, the second sentence of my notes describes the day as 'the slowest to date. All forward momentum on the future park had ceased, and their creative energies were targeted on a promotional book intended for big-donor investors.

The grinding halt by March 2012 was all about the money required to complete construction, but more precisely it was about permits. Building regulations required that any commercial project, irrespective of its industry, be completed within a two-year timespan. If an initiated project is unable to do so, construction would be legally demanded to cease until all permits were renewed. Renewal meant months of processing time and substantial fees. For Ark Encounter to begin construction without all the finances in order would 
be bad business, but the decision to wait also makes sense in religious publicity terms. An indefinite delay mid-construction would not just be embarrassing; it would de-legitimize AiG's ongoing effort to bolster the reputation of creationism. As a result, applying for permits with legally binding groundbreaking dates had to wait until all finances were secured. In December 2010, the ministry was confident that the necessary funds could be raised in a year's time. They miscalculated.

The opening of Ark Encounter dramatically marked AiG's cultural and economic power, but this structurally induced waiting marks how the process was always contingent on the ministry being an actor subject to the requirements and timelines of state regulation (Auyero 2011). There are no religious exemptions in the world of building permits. Of course, this too was made meaningful by the team. Delayed responses from government officials, unexpected wait times, lengthy applications, substantial fees: these all became fodder for how 'secular bureaucracies' fail and impede 'God's work'.

The subsequent two years were filled with multiple fundraising events and activities. The most productive was an investment bond programme that launched in the autumn of 2013. The bond was offered at two levels: a maximum of $\$ 250,000$ and a minimum of $\$ 5,000$. The ministry's promise to investors was: purchase a bond to help make Ark Encounter a reality and reap the financial reward when the park succeeds. To promote the bond, and as an adrenaline shot in the arm of AiG's religious publicity, the ministry organized a debate between Ken Ham and the pro-science, pro-evolution celebrity Bill Nye in early February 2014. The two-anda-half-hour debate was held at the Creation Museum for an audience of 900 and live-cast online for millions of viewers. As of October 2017, the version archived on AiG's YouTube channel had received more than 6 million visitors.

The exact relation between the debate and the bond earnings is unknown; the latter is not public record. But, on 27 February 2014, AiG hosted another live webcast event: a 45 -minute announcement that the necessary funding had been secured and the future of Ark Encounter was assured. Construction would begin later in the year and the park would open in summer 2016. The period of protracted uncertainty had ended and a more anticipatory waiting began.

As all this unfolded, so did my methodological journey. Much like anyone interested in issues of religion in the United States, I was intrigued by the announcement of Ark Encounter. I was further intrigued given the fact that the ministry's headquarters were located a one-hour drive from the university town where I was living and teaching, and the fact that I had just concluded a different project. My thought at the time: if I could gain access to the behind-the-scenes 
production of a creationist theme park, that would be an anthropological story worth telling.

I first contacted Answers in Genesis in April 2011, and received my first reply a month later. The email came from Ark Encounter's main administrative assistant, who connected me with Mike: one of AiG's co-founders and the Ark's Chief Action Officer. I conducted an interview with Mike in late August 2011, after three months of emails and rescheduled meetings. The interview was as much about Mike acting as a gatekeeper for my ethnographic proposal as it was any questions I wanted to ask. Six weeks later, in mid-October 2011, I began my visits to the design studio.

My initial visits included lengthy boardroom meetings, where the creative team brainstormed numerous park details. I recall being impressed by the fluidity of the meetings. The team moved seamlessly from strategies of themed immersion to theological priorities to practical details, such as where restrooms and food stands should be located. I also recall the feel of halted creative momentum in spring 2012, when the opening date shifted from approximate to unknown. For the next two years, my time with the team oscillated between periods of slow, steady labour and abrupt, stressful deadlines. As I detail below, their work designing Ark Encounter could only progress so far until the budget and timeline were definite. In the meantime, they worked on other projects, from Ark promotional materials to a new Creation Museum exhibit to contracted work with another museum. In June 2014, my access to the team ended, an intense fieldwork moment I recount below. Reflecting on my experience with the team from October 2011 through to June 2014, I realize that my own waiting was an instructive part of the ethnographic process.

\section{Creative ceiling}

The creative team's labour was fundamentally altered by the fundraising delay. Initially, they were tasked with designing the entire park - the ark, Babel replica etc. Each of the core creative team members would serve as the creative director for an attraction, and they would hire other artists to work under them. With the shift to a phased opening, the team rejoined as a single collaborative unit to design the 100,000+ square feet of themed exhibit space onboard the ark. They would eventually hire a few other artists, but the phased opening allowed them to remain a small, concentrated team. 
Only limited design progress could be made on Ark Encounter before the necessary funds were secured. This was a major refrain throughout my time with the team. There was a sort of creative ceiling, fixed low in place until questions of budget and timeline were finalized. I was told repeatedly that you can only dream so much as an artist before you have to rein yourself in and wait for certain pragmatics to be decided: how much money will we have for a particular exhibit, how many artists will be devoted to its completion, how much time will we have to finish before shifting to the next exhibit? As one artist described it over lunch one day, they were stuck in a 'holding pattern'.

There is a co-dependent relationship between budget and creative labour. The money available determines numerous artistic choices, from exhibit size to the kinds of materials that can be used and what forms of technology are available. A good example is the design of the 'pagan pathway', as it was termed in the first design meeting I observed in November 2011. The path was initially a 20 -foot wide, 1,500-foot long walkway that would lead visitors to the ark. Although a minor feature compared to the mass of exhibits planned for onboard, the path always held special importance for the team because it was the first major place where visitors would be immersed into 'the pre-flood world of Noah'.

Details for the pathway's design were a substantial part of team meetings in late 2011 and early 2012. From the start, the team was attentive to the fact that the pathway's budget was limited. Their early brainstorming focused mostly on a series of objects that would variously populate the pathway, combining to depict an 'evil society' that God judged with death. In a February 2012 meeting, the design focus shifted to what kind of barrier would be used to form the boundaries of the pathway. Patrick suggested a series of banners and flags rising to different heights, each signifying immorality and corruption, to provide a 'vertical visual' effect. All applauded this idea, especially as an alternative to the possibility of a painted or decorated wall. As one artist said discouragingly, 'A painted fence looks like a painted fence. You don't want to defeat the experience.'

When the funding shifted from delayed to uncertain, all work on the pathway stopped. They had a definite theme - depicting the 'pagan wickedness' of the pre-Flood world - but without a budget or a timeline, the question of how to realize that vision could not be answered. By late autumn 2013, the bond offering had introduced some certainty into the fundraising process and the team had returned to preliminary work for the ark. The first task for one of the artists was to revisit the pathway. The 
new idea was to focus only on objects that would sit on the path. The artist designed six stele monuments, eight to ten feet tall, that would 'tell the story' of pre-flood life, from creation in the Garden of Eden to the sinful world of Noah's day.

By June 2014, the stele approach was decided against and they were back to a painted mural on a wall lining the pathway. Eventually, the team resigned themselves to the fact that they did not have the necessary budget or time for the pathway at all. Instead, the painted mural would need to go inside the ark as part of a Deck Two exhibit that visibly and audibly portrays the progression from creation to the flood. As you approach the mural (see Figure 5.3), the soundscape shifts to a collage of choreographed noises: sacrificial killing, yelling, raging fires, hedonistic cheering, and sword fighting.

I wonder now whether the team was disappointed with the decision for a mural and the eventual elimination of the pathway altogether. I wonder too if the nearly two-year period of protracted uncertainty disturbed the team's creative momentum and energy. Without the stalled interruption, could they have imagined a more engaging alternative? After all, 'a painted fence looks like a painted fence'. Did waiting produce a creative product that did not fully satisfy the team's expectations for immersive entertainment?

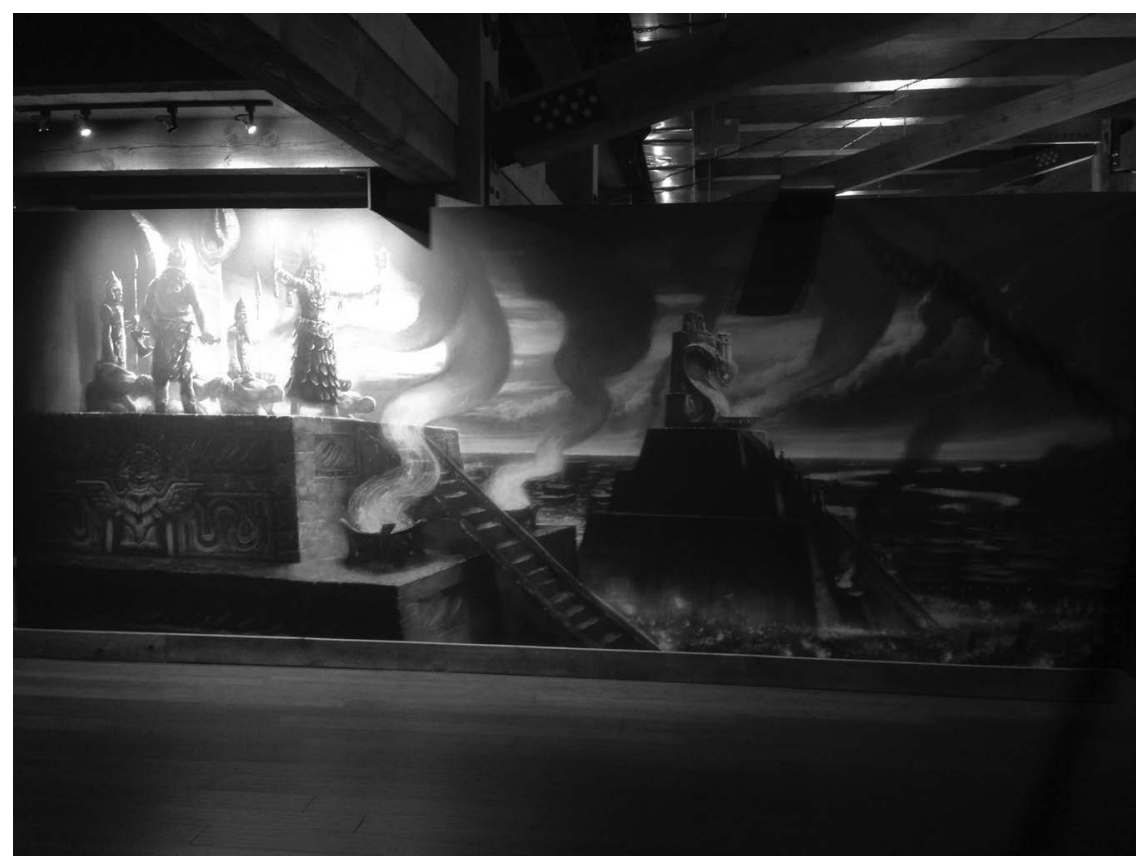

Figure 5.3 Pre-flood mural at Ark Encounter. Photo by author 


\section{In the cubicle}

From October 2011 through to June 2014, the ethnographic backbone of my fieldwork was the team's daily creative labour: spending mornings and afternoons at the design studio while they drew freehand, illustrated concept art, worked with raw materials, sketched exhibit schematics, edited and critiqued each other's work-in-progress. I talked with the artists at their cubicles, took notes during planned and impromptu team meetings, listened to lunchtime work talk and photographed the ubiquitous art sitting on tables, hanging on walls and torn up in trash cans. I arranged semi-structured interviews with team members, but the majority of audio-recordings and field notes addressed the work of a small team working from small desks: usually tedious, frequently under deadline, ever-conscious of budgetary constraints and constantly seeking the next imaginative breakthrough.

The very fact of being granted access to the making of a multi-milliondollar creationist theme park is flush with excitement. In first imagining this project, I envisioned sometimes raucous team meetings, debating design ideas and witnessing the rush of creative exploration. Much to my delight, my time at the studio in late 2011/early 2012 included several such meetings. Truth being stranger than fiction, the reality of the matter was more interesting than my imaginings. Perhaps not as raucous, the meetings were intense and replete with fascinating elements.

Then came the uncertainty. There were still team meetings, but they had been drained of all urgency. There were plenty of deadlines, but they were for finishing promotional materials, not finalizing an exhibit for installation on the ark. My fieldwork days became dominated by one particular form of research labour: sitting next to the artists in their cubicles while they worked. On average, I spent four to five hours at the studio each visit. A great deal of this was spent waiting: for the right moment to ask questions, for private meetings to finish so I could follow up, for artists to return from running errands. When I first arrived at the studio, I was given only one condition. Do not impede anyone's work. I took this seriously, knowing that my continued access to the team was dependent on not being perceived as a distracting nuisance. Always cautious about disturbing their progress, I would sit silently as they worked. I never quite perfected the skill of selecting the right opportunity to ask about the creative labour happening in the moment. I did find that waiting for print jobs to finish or, even better, waiting for large computer files to back up, provided useful openings. 
The truth is that my fieldwork at the design studio involved significant experiences of boredom. Rather than the productive confusion that ethnographers champion as central to the process of learning and socialization, conducting research in this setting entailed the stilling and slowing of spacetime (Anderson 2004). When not actively engaging the team in talk about their art, I took a lot of pictures, browsed bookshelves and read any materials they were able and willing to share (e.g. art books they were consulting for a project, preliminary scripts for an exhibit). Still, substantial time was left to wait and the space for waiting was confined to a few places in the studio. Eventually, I decided boredom was an unavoidable experience. I never liked it, sometimes dreaded it on the hour-long drive to the studio, bemoaned it on the hour-long drive home, and frequently felt awkward in the midst of it - but I learned to accept it.

This description likely rings true for anyone who has conducted ethnographic fieldwork. Malinowski's diary and countless other volumes report 'long periods of boredom occasionally punctuated by events that broke the monotony' (Chung 2009: 65). However, unlike some other accounts of ethnographic boredom, the waiting I experienced was not a byproduct of everyday life or an instrumental component of ritual action (Sjørlsev 2013). It was a necessary form of action, a dull discipline that I dedicated myself to in order for my status not to flirt with what I wanted most to avoid: being a distraction.

Another form of waiting I experienced during 43 months with the team was the anxious waiting for my ethnographic access to be revoked. This finally happened in June 2014 (see 'Calling it quits' below), but prior to this I halfexpected every return to the studio to be my last. This motivated me, even more so than previous ethnographic projects, to capture as many details as humanly possible on every visit; hang on every word, take as many pictures as possible, be as fully engaged in every fieldwork moment as possible. I realized after a while that the team was also waiting for me. Journalists regularly pass through the studio, and the team is overly familiar with being interviewed once and then being written about soon after, often in a register of merciless, mocking criticism. Despite my attempts to explain how ethnography was different, it was only my continued presence that convinced the team that I was not akin to just another journalist passing through. I recall arriving at the studio one morning, six months or so into the fieldwork, and being greeted with the surprised comment, 'James, you're back!' As more time unfolded, the team asked me one question more than any other: 'When are you going to write something?' 


\section{Idle hands}

When Ark Encounter's fundraising slowed to a crawl in spring 2012, and the park's opening was delayed indefinitely, the team's labour changed. It did not stop. The feverish atmosphere I first encountered around the studio in autumn 2011 evaporated, but the work never paused.

Through mid-autumn 2012, they completed a series of projects that were much more about fundraising than advancing the team's vision for the park. For example, they spent six months drafting, editing and finalizing a 60-page, glossy printed promotional booklet that presented the basic rationale for Ark Encounter, outlined the design of the three decks, presented concept art for major exhibits and explained how the ark expanded the religious publicity of the Creation Museum. The primary audience for the promotional book was committed creationists; or, more precisely, financially flush and/or generous creationists. For the team, the promotional book exemplified the problem of the creative ceiling. It helped clarify the overall vision for the three decks and flagged a few potential design problems, but none of the exhibits could be anything more than a rough, conceptual sketch.

From November 2012 through to May 2013, their work shifted away from Ark Encounter in two directions. First, they were tasked with creating a new exhibit for the Creation Museum welcome portico in time for the summer 2013 tourist season. The exhibit, 'Dragon Legends', was a colourful, eight-case display of the creationist argument that the presence of dragon tales around the world is a proof that humans and dinosaurs coexisted (Bielo 2016b) (see Figure 5.4).

The two artists who primarily created Dragon Legends described it as a helpful artistic break from their creative labour with the ark. 'It's a more playful, fun thing; just a fun, expressive way to tell stories', one of the artists explained. He contrasted this with Ark Encounter, which he described as 'hyper-realism', offering fewer opportunities to 'go stylized'.

The second direction was some contracted labour. As they had done several times in the past, the team accepted an offer to complete work from an outside business. In this case, it was a creationist-owned natural science museum in Alabama that wanted to completely redesign their facility. A large project in its own right, the team accepted it on the condition that Ark Encounter was the team's first priority once the funding was secured. As long-time supporters of AiG, the Alabama museum owners agreed.

Along with this steady stream of projects, the team avoided the problem of idle hands by consuming some creative inspiration together. For example, they 


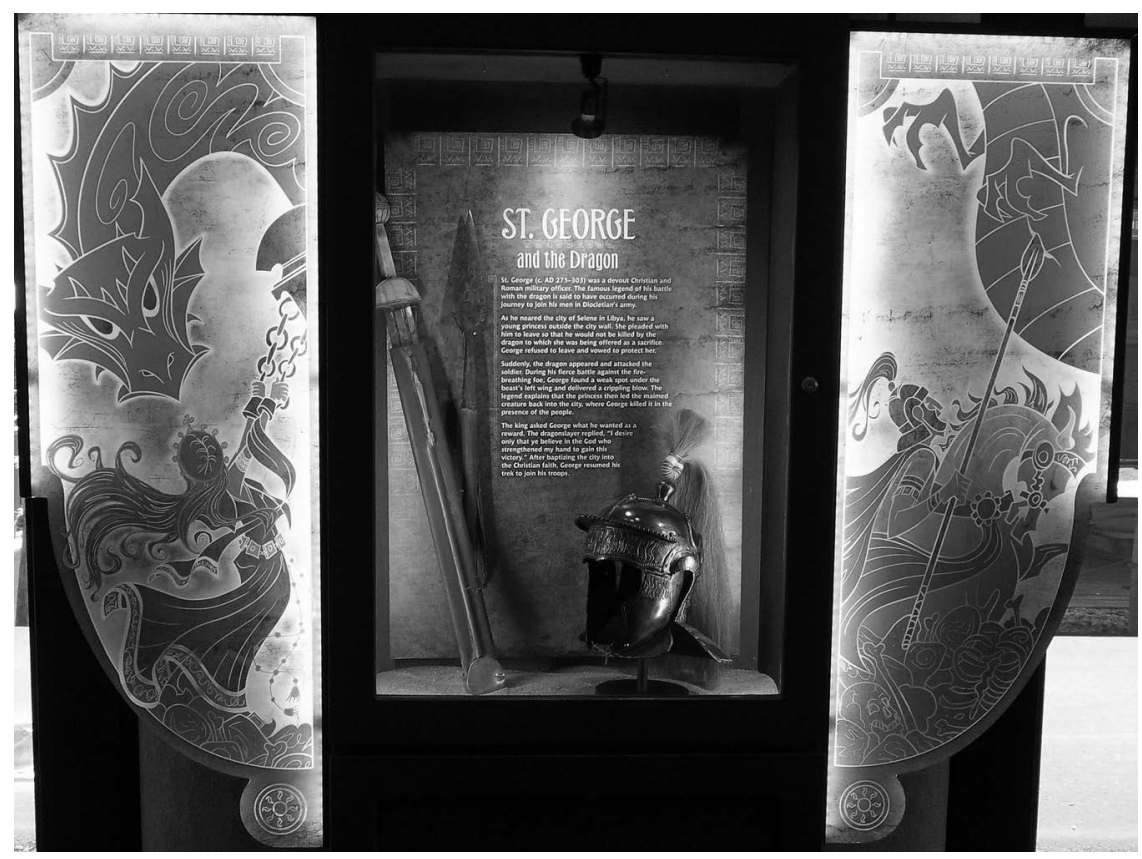

Figure 5.4 Example of Dragon Legends display case at the Creation Museum. Photo by author

travelled to other museums and attractions to collect design ideas and make observations about practical choices to mimic or avoid regarding park amenities. In May 2012, they returned to one of their favourite sites, the Lincoln Museum in Springfield, Illinois. When I saw them at the studio the next day, they were full of renewed enthusiasm. Patrick described it as 'the best museum out there, period. He added how this trip was especially good for reminding them to keep their focus on 'the so what' of the Noah story. 'The flood was an event in history, but so what, who cares?' Answering his rhetorical question, Patrick continued by stressing the creationist claim of a common ancestry that traces to Noah and his family: 'none of us would be here if it weren't for Noah'. He closed by returning to the question of park design, and how to use 'the so what' to create a memorable experience, 'to make a linear row of boxes interesting'.

The team headed for their cubicles when the meeting ended. Before they began the day's labour, I asked the three main artists what they gleaned from revisiting the Lincoln Museum. For one artist, it was a time-lapse display that depicted the Civil War's unfolding, complete with a rising death toll and battle locations. Another focused on the experience as a whole rather than a single exhibit, and how successfully the Lincoln Museum 'told the story visually, 
mostly without words'. This echoed a regular critique the team voiced of their previous work on the Creation Museum. They all wanted Ark Encounter to rely less on textual signage to teach, and more on the embodied experience of being in a designed space. Finally, I asked if visitors needed to have much background knowledge about the Civil War to fully appreciate the museum. Together, two artists immediately said 'no', the Lincoln Museum does a beautiful job of teaching to the broadest possible public. They reflected that this is one of their key commitments with Ark Encounter. They want all visitors, no matter what their biblical literacy might be, to be equally engaged.

\section{Calling it quits}

Throughout my fieldwork with the team I never lost a sense of anxious waiting. I never stopped wondering when they might decide to sever my ethnographic access. This anxiety dissipated a bit in late autumn 2013 after Patrick and I had a frank conversation. The bond programme was in full swing and the ministry was hopeful that it would deliver the needed funds. Following an interview in his office, Patrick informed me that my fieldwork could not continue in its current form once the funding was secure. The team would be too busy and even minor distractions in the studio could disturb the creative process. In turn, we outlined an agreement for how my fieldwork could continue, primarily focusing on collective team meetings. I left the meeting feeling assured.

Then, in June 2014, it happened. I suspected as much from the email exchange that led up to the visit. The reply from the administrator came within a few hours, which had never happened before. It read only: 'Monday June 30 at 2pm will work for us. You will be meeting with Patrick. If you have any questions just let me know. My suspicions were confirmed when I arrived. Patrick stood to welcome me in his office and closed the door behind us; he had never done this before.

After a few pleasantries, Patrick moved swiftly to his purpose: 'we have to call it quits. It was certain, even stern. Before I could respond, he added that this extended to team meetings; everything. I reminded him of our discussion a few months prior and asked what had changed. He did not really acknowledge the previous agreement, just continued that it was too much effort to involve 'an outside person', and that the meetings were 'private'. The decision was clearly final, non-negotiable. We talked for nearly another hour, Patrick updating me on their progress since my last visit and their plans 
for moving forward. It was difficult to concentrate. I was upset and even embarrassed, like a romantic partner who breaks up with you with no chance to defend yourself or appeal your case. He walked me to the door, another first in 43 months, and wished me well.

The drive home was a chaos of emotion. In the subsequent days, I realized I was wrestling with at least four distinct feelings. I was angry with Patrick for dismissing our earlier agreement. I was disappointed; my research design of following the team's work from beginning to end was cut short. Strangely, I was relieved. The difficulties of the fieldwork had become cumbersome: visits cancelled at the last minute; arriving to the studio only to find most of the team not there for one reason or another; the tedium, awkwardness and boredom of sitting in the cubicles. A burden I had learned to embrace was suddenly gone, and it was freeing. If I was not allowed to be there again, that meant I would not ever have to be there again. Tagging alongside relief, was guilt. I had dedicated a lot of time to this fieldwork; feeling relieved felt a bit shameful. In any case, the other shoe had finally dropped and one period of waiting was over.

\section{God's time}

Another refrain that punctuated my fieldwork resonates deeply with fundamentalism more broadly. Throughout the months of uncertainty, team members imbued the process of waiting with sacred meaning by reminding themselves and each other that the funds would come through 'in God's time.' As time passed and the waiting became indefinite, the team began to question when and how the funding would be secured, although, apart from the rare moment like Patrick's in the opening vignette, they remained committed to the hope that the project would eventually materialize.

Charismatic Christians are known for the tremendous energy they devote to discerning and bringing their own will into alignment with God's will (Bialecki 2016). American fundamentalists put less work into discerning and more into 'submitting' to God's will. Part of this submission process is figuring out what forms of agency are available to them as committed believers; what they can do as faithful people that will demonstrate trust and submission. For the team, this meant continuing their creative labour, designing promotional materials and completing other projects. God would deliver the money when 'He' was ready; in the meantime, and in preparation for God's timing, they had work to do. In this way, uncertain waiting became an opportunity for the team to 
live in proper fundamentalist dispositions. Doubt became fertile soil for faith (Pelkmans 2013).

During morning prayer meetings, as asides in the middle of work talk, and during lunchtime conversations I heard slight variations on the same theme: Ark Encounter is 'in God's hands', and it will happen (or not) according to 'His will, not ours'. In October 2012, I rode with two of the artists to eat lunch at a nearby sushi restaurant. On the way, I asked about a large donation that had been mentioned during the morning meeting. In an excited tone of awe, they described how an older woman delivered a cheque, completely unannounced, for $\$ 300,000$ earlier that week. She was not a regular contributor to AiG, she just wanted to support Ark Encounter. They framed the woman and her gift as a reminder from God to 'be patient' and 'shut up'. Rather than complain about the stalled fundraising, they should use their creative labour to do their part and trust God to deliver the rest. Patience - like boredom and hope, endurance and uncertainty - is yet another experiential register of waiting. For the team, patience is a performance of faith, a form of agency in which they become ideal Christian subjects who, remembering Proverbs 3 , trust in the Lord with all their heart and lean not on their own understanding.

As they waited, tried to trust God's timing over their own and scanned their lifeworlds for reminders, they recreated another familiar fundamentalist pattern. Just as Noah continued building the ark and waited patiently for the promised storm, the team continued their creative labour and waited for the flood of investment dollars. The fundamentalist practice of locating themselves in scripture and elaborating on the connections between themselves and biblical characters is well established. Most notably, Susan Harding (2000: 231- 234) closely analysed how Jerry Falwell's rhetorical poetics were built on this kind of typological hermeneutic. Falwell placed himself in the drama of scripture, and asked his audiences to listen to him as a modern type of biblical voice.

The creative team understands Ark Encounter in much the same way: not as a fulfilment of prophecy, but as a re-enactment of Christian truth. Just like the ancient heroes of biblical tradition, and the icons of modern fundamentalism, Ark Encounter will testify to the authority of scripture and the moral-spiritual value of creationism. This commitment was always available for impromptu elaboration, for new ways to reassert who they are, what they are doing, and why the realized vision was worth the wait. For example, I arrived at the studio one morning in March 2012 to find the team seated around the boardroom table, talking casually after a short morning meeting. The conversation turned to a new 'documentary' that would be released in limited theatres at the end of 
the month: Monumental, starring Kirk Cameron, a handsome celebrity face of contemporary fundamentalism. The lead administrative assistant encouraged everyone to see the film and tell others to do the same. Cameron funded the film himself and if it grossed a certain dollar amount a major media company would purchase the rights and distribute the film nationally. Monumental repackages the typical fundamentalist narrative that America is in a moral and spiritual freefall. In response to a summary of the film by one of the administrative assistants, Patrick described America as 'done', citing public schools as a prime example. Jon and Kristen seemed to want a more hopeful tone, adding that 'God is sovereign' and 'everything will work out for the glory of God and for God's people'. Undeterred, Patrick continued that American Christians never talk about 'revival' and are failing to be any different than those causing the moral decline. To close, he reminded the team that Monumental's essential purpose rhymed with Ark Encounter's: 'That's why what we're doing is so important. It's going to be this weird little beacon of hope to remind people that we are different.' With that, the team dispersed to their cubicles.

To wait in a way that performs trust in God and submission to God's will includes paying attention to God's reminders. Waiting was at times frustrating and anxiety provoking for the team, but it also created opportunities to witness God working. It was an active form of waiting, using the strategy of scanning everyday life for signs of divine presence and action. A premier example is the narrative that God brought these specific individuals together for the purpose of building the AiG empire of religious publicity. This narrative was performed in front of 900 people at the 'Hammer and Peg Ceremony', a celebratory event in early May 2014 held at the Creation Museum. The all-day event brought together Ark personnel, AiG board members, local politicians and donors as a kind of ceremonial groundbreaking. Following presentations on the development of Ark Encounter, donors were bussed from the museum to the Ark property so they could walk around the building site.

The presentations included an onstage discussion between Ken Ham and Patrick. Ham acted as interviewer, while Patrick fielded questions about the exhibits visitors could expect. To introduce Patrick, Ham told a story about a different period of waiting, the thirteen years between the founding of AiG and the opening of the museum. During this time Ham 'prayed for God to deliver someone' who was capable of designing the museum. That someone turned out to be Patrick, who was hired in the autumn of 2001, just after the groundbreaking. Ham jokingly recalled how Patrick informed them that they had done everything backward: securing a building before finalizing the plan. 'We're not doing that 
again,' Patrick assured the audience to an appreciative laugh. Ham added: 'This time, more design, less evolution,' a bit of creationist speech play that the audience happily devoured.

As their interview progressed, Ham asked Patrick about the artists he had assembled to design Ark Encounter. Patrick lauded the team, describing them as 'wonderful' and that he 'couldn't do it without them'. He noted assuredly that 'God provided' each and every one of the artists. Again, Ham was ready with a crowd-pleasing creationist quip: 'As God brought the animals to Noah.'

\section{Conclusion}

This chapter has explored how protracted uncertainty and anticipatory waiting in the making of a creationist theme park were filled with action and meaning. Ultimately, the observations made here aim to complement this volume's broader effort to foster a comparative anthropology of waiting. In particular, I hope to have advanced an approach to waiting as a phenomenologically rich and agentive process. Like Hage (2009) and Brun (2015), amongst others, the waiting experienced by the Ark Encounter team was active in multiple ways. I argued that the interplay of questioning of how 'God's plan' will unfold, fundamentalist dispositions and creative labour were central to the team's experience of waiting. This complements other scholarship on the social life of doubt, namely the capacity of doubt to breed faithful commitment (Pelkmans 2013). With respect to the latter, my aim has been to draw out some ways in which waiting is coupled to the production of religious publicity. While the team was at the mercy of a broader ministry, donors and political-economic conditions, their focus remained on how their creative labour could promote and help bring about Ark Encounter's eventual realization. All religious publicity emerges from contexts of production (Engelke 2013). As we continue to trace how religious publicity is produced, the Ark team's experience will help remind us that the forms of waiting that punctuate production processes are revealing and worthy of attention in their own right.

With respect to my fieldwork, waiting was a pivotal component of the ethnographic experience. There were certainly frustrations involved with doing this particular species of ethnography, but it is also true that waiting likely enabled this fieldwork to exist at all. I hope other ethnographers, particularly those working in contexts of cultural production, will benefit from the reflections about how I waited, the conditions of my waiting, and the methodological and reflexive value that is available in analysing waiting. 
The forms of waiting examined here echo some of the central contributions to this volume. Waiting is not an empty form of temporality, but can be integral to processes of becoming. Waiting is not necessarily lacking action, but can itself be a form of social practice comprised of multiple forms of doing. Moreover, one form of waiting can be closely linked with other forms of waiting, and their meanings and affects are intertwined with one another. While waiting is defined by its status as an in-between experience, it can also be much more. Waiting can reflect the structural conditions it emerges from and into; work as a register for performing religious dispositions; and, be a form of experiential action integral to the craft of ethnographic fieldwork.

\section{References}

Anderson, Ben. 2004. 'Time-stilled Space-slowed: How Boredom Matters'. Geoforum 35: 739-754.

Auyero, Javier. 2011. 'Patients of the State: An Ethnographic Account of Poor People's Waiting. Latin American Research Review 46(1): 5-29.

Bialecki, Jon. 2016. 'Diagramming the Will: Ethics and Prayer, Text, and Politics'. Ethnos 81(4): 712-734.

Bielo, James S. 2016a. 'Materializing the Bible: Ethnographic Methods for the Consumption Process'. Practical Matters 9: 1-17.

Bielo, James S. 2016b. 'Creationist History-Making: Producing a Heterodox Past'. In Lost City, Found Pyramid: Understanding Alternative Archaeologies and Pseudoscientific Practices, edited by Jeb J. Card and David S. Anderson, 81-101. Tuscaloosa: University of Alabama Press.

Brun, Cathrine. 2015. 'Active Waiting and Changing Hopes: Toward a Time Perspective on Protracted Displacement'. Social Analysis 59(1): 19-37.

Butler, Ella. 2010. 'God is in the Data: Epistemologies of Knowledge at the Creation Museum'. Ethnos 75(3): 229-251.

Chung, Jae A. 2009. 'Ethnographic Remnants: Range and Limits of the Social Method' In Fieldwork is Not What it Used to Be: Learning Anthropology's Method in a Time of Transition, edited by James D. Faubion and George E. Marcus, 52-72. Ithaca, NY, and London: Cornell University Press.

Engelke, Matthew. 2013. God's Agents: Biblical Publicity in Contemporary England. Berkeley: University of California Press.

Hage, Ghassan. 2009. 'Introduction' In Waiting, edited by Ghassan Hage, 1-12.

Melbourne: Melbourne University Publishing.

Harding, Susan F. 2000. The Book of Jerry Falwell: Fundamentalist Language and Politics. Princeton, NJ: Princeton University Press.

Jansen, Stef. 2014. 'On Not Moving Well Enough: Temporal Reasoning in Sarajevo Yearnings for “Normal Lives"'. Current Anthropology 55(9): s74-s84 
Kwon, June Hee. 2015. 'The Work of Waiting: Love and Money in Korean Chinese Transnational Migration'. Cultural Anthropology 30(3): 477-500.

Numbers, Ronald L. 1992. The Creationists: The Evolution of Scientific Creationism. Berkeley: University of California Press.

Pelkmans, Mathijs. 2013. 'Outline for an Ethnography of Doubt'. In Ethnographies of Doubt: Faith and Uncertainty in Contemporary Societies, edited by Mathijs Pelkmans, 1-42. New York: I.B. Tauris.

Sjørlsev, Inger. 2013. 'Boredom, Rhythm, and the Temporality of Ritual: Recurring Fieldwork in the Brazilian Candomble. Social Analysis 57(1): 95-109.

Stromberg, Peter. 2009. Caught in Play: How Entertainment Works on You. Stanford, CA: Stanford University Press.

Trollinger, Susan L. and William V. Trollinger, Jr. 2016. Righting America at the Creation Museum. Baltimore, MD: Johns Hopkins University Press. 